\title{
Biochemical and Histological Effects of Calcitonin Hormone on Female Sailfin Black Molly (Poecilia Latipinna)
}

\author{
Original \\ Article \\ Sarah T. Al-Saray ${ }^{1}$ and Ali A.A. Al-Ali ${ }^{2}$

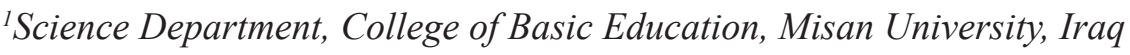 \\ ${ }^{2}$ Biology Department, College of Education for Pure Science, Basrah University, Iraq
}

\begin{abstract}
Introduction: Calcitonin $(\mathrm{CT})$ regulates blood calcium $(\mathrm{Ca}+2)$ levels in mammals, but the results of experiments on its role in fish are uncertain, its functions exceeded the limits of regulation of $\mathrm{Ca}+2$.

Aim: This experience represents a trial to remove that ambiguity and determine role of calcitonin by clarifying its relationship with different biochemistry parameters. Therefore, we investigate the effect of (CT) on some biochemical parameters of blood in female fish Poecilia latipinna, these are $\mathrm{Ca}+2$, urea, creatinine, alkaline phosphatase enzyme (ALP), follicle-stimulating hormone (FSH) and luteinizing hormone (LH). The study also deals with the follow up of histological changes that are caused by (CT) in the liver, kidney, and intestines of the fish.

Material and Methods: The fish were brought from ornamental fish shops and were adapted and reared in the laboratory. The sample of fish was divided into two groups; The first group was injected with 4 microliters of (CT) for ten consecutive days. At the end of the experiment, blood was drawn from the fish and then it anatomized and tissue sections of organs under study were prepared.

Result: The finding show calcitonin works to reduce level of $\mathrm{Ca}+2$ in the blood with a significant difference $(0.03)$ at the probability level $\mathrm{P} \leq 0.05$. And was not affected urea and creatinine by the hormone, while the level of ALP enzyme increased with a significant difference $(0.04)$ at the probability level $\mathrm{P} \leq 0.05$. With sex hormones, the effect was limited to LH without FSH. LH levels increased significantly with $(0.02)$ at $\mathrm{P} \leq 0.05$. CT caused histological changes in the kidney and intestines, while the liver was not affected by (CT).

Conclusion: Calcitonin has been shown to play a role in $\mathrm{Ca}+2$ regulation in fish blood and its work overlaps with different organs of the fish body.
\end{abstract}

Received: 21 October 2019, Accepted: 09 November 2019

Key Words: Alkaline phosphatase enzyme, calcitonin, calcium, poecilia latipinna.

Corresponding Author: Sarah T. Al-Saray, MSc, Department of Sciences, College of Basic Education, Misan University, Misan, Iraq, Tel.: +9647712416198, E-mail: saraalsaray@uomisan.edu.iq

ISSN: 1110-0559, Vol. 43, No.2

\section{INTRODUCTION}

Calcitonin (CT) is a peptide hormone secreted by the thyroid gland, it reduces the concentration of calcium $(\mathrm{Ca}+2)$ in the plasma, which is produced from $\mathrm{C}$ cells adjacent to the thyroid follicle in mammals. Whereas, $\mathrm{C}$ cells concentrate and form a specialized gland called ultimobranchial in lower vertebrates ${ }^{[1]}$.

The normal function of calcitonin in mammals is represented in its role the balance of blood calcium ${ }^{[2]}$. It leads to Hypocalcemia, counter-action with parathyroid hormone $(\mathrm{PTH})$ in regulating concentration $\mathrm{Ca}+2^{[1]}$. However, studies differed in its effect on blood calcium in fish depending on species and protocol ${ }^{[3,4]}$. Some studies have confirmed that its role in fish is similar to that in mammals, such as studies on carp Cyprinus carpio ${ }^{[5]}$, Danio Rerio ${ }^{[6]}$ and Poecilia latipinna ${ }^{[7]}$. Whereas, the action of the hormone on hypocalcemia has not been established in some species ${ }^{[8-11]}$. Which opened the way for many research to determine the actual role of this hormone in fish, studies suggested that it has a role in the regulation of reproduction ${ }^{[12-15]}$. Studies have indicated that there is a relationship between the level of CT and some sex hormones in the plasma, but they have not been able to explain that relationship ${ }^{[5,16,17]}$. Other functions of $\mathrm{CT}$ have also been reported in fish, suggesting that topically produced CT in the small intestine may inhibit calcium absorption during feeding ${ }^{[18]}$. Also, that $\mathrm{CT}$ in serum maintains the balance of calcium in bone to prevent resorption of bone ${ }^{[19]}$. mRNA encoding of $\mathrm{CT}$ receptor has been detected in a number of flounder fish tissues, indicating the diverse functions of CT in adult fish ${ }^{[20,21]}$. Calcitonin gene CGRP was found widely distributed in the tissues of Fugu rubripes, but most of its gene expression was in ultimobranchial gland and brain $^{[22]}$. No specific function for it in fish has been known yet, which requires further studies on its relationship with different body tissues to clarify its role ${ }^{[11]}$. One potential task of this distribution is that it acts as a Neuropeptide ${ }^{[22]}$.

The present study investigated the effect of calcitonin on some biochemical parameters $\mathrm{Ca}+2$, urea (Ure), creatinine (Crea), alkaline phosphatase enzyme (ALP), 
follicle-stimulating hormone (FSH) and luteinizing hormone (LH). In addition, the study of histological effects on some organs represented by liver, kidney and intestines in the fish P. latipinna. In an attempt to answer the questions posed about it.

Molly fish has been chosen as a laboratory model in the current study because these organisms have become important in the world of biology such as Drosophila, as it has recently become a model organism in the study of embryo development of vertebrates and genome research $^{[23,24]}$. These organisms are instrumental in better understanding the molecular and cellular mechanisms that lead to pathological conditions, and in developing new diagnostic and treatment tools ${ }^{[25]}$. And, it represents a powerful platform for cancer research and the improvement of targeted therapies ${ }^{[26]}$.

$\mathrm{Ca}+2$ is the most important component of solid tissue. Physiologically, it regulated by thyroid hormones (PTH) and (CT), PTH increases its level in the blood, and when its levels rise, the hormone CT decreases $\mathrm{it}^{[1]}$. Crea is a form of keratin consumption in muscles, and ure is produced from the amino acid metabolism and is formed in the liver, they are the final products of metabolism that the body does not need. They are very poorly absorbed during glomerular filtration. Thus, almost all ure and Crea filters are excreted in the urine ${ }^{[1]}$. ALP enzyme from plasma enzymes, which produced mainly in the liver and bones and it is less in the intestines and kidneys, and it is made in the placenta during pregnancy ${ }^{[27]}$. FSH and LH are important sex hormones produced by the pituitary gland, that regulate growth and puberty, reproductive processes in the body and control of reproductive system ${ }^{[28,29]}$. In this study we attempt to determine the true role of calcitonin in fish by clarifying its relationship with different biochemistry parameters in the fish.

\section{MATERIALS AND METHODS}

The mature P. latipinna females were brought from ornamental fish shops and transferred to the laboratory at the University of Basra / Department of Life Sciences. Females were selected from the pure black breed, averaging 5 centimeters long and weighing 5 grams, respectively, and fish were divided into two groups; each comprising approximately 100 fish. The aquarium were under the same laboratory conditions (water temperature range of 28 - $24 \mathrm{C}$, water salinity rate $0.7 \mathrm{ppt}, \mathrm{Ph}=7.5$ ). fish were fed on a commercial paper diet as mixed feed, in addition animal feed represented by frozen Artemia. Fish group I were injected at a size 4 microliter of Calcitonin (CT) per 5 $\mathrm{g}$ fish weight, equivalent to $1 \mathrm{IU}$ per $100 \mathrm{~g}$ fish ${ }^{[11]}$, group II fish were injected with a normal saline of $0.6 \%$ and used as a control group. Fish were injected for 10 consecutive days daily in the trunk area below the dorsal fin.

Ten days after the injection, blood was pull from the fishes of the two groups with five replicates from each group. The procedure was done by cutting the tail and pulling blood with the capillary property by Hematocrit and assembling them into small tubes (Eppendorf). Blood samples (after clotting) were placed in the centrifuge (Centrifuge 5424 Eppendorf) to obtain the serum. The ratio of the studied parameters in blood was measured using the Chemistry Analyzer (Mindray BS-200). We used kits from a company (Monobind inc.) to analyze hormones (FSH and LH), and kits from a company (Accent 200) to analyze other parameters. After the blood was drawn, the fish were anatomized to obtain organs liver, kidneys and intestines, which were fixed by Bouin's fixative and preparation of tissue segments from them in the usual way, using stain of hematoxylin and eosin $(\mathrm{H} \& \mathrm{E})^{[30]}$. After obtaining the data, it was statistically analyzed by the statistical program SPSS and the T test was adopted to show the statistical differences of the studied criteria between the control and treatment groups.

\section{Ethical Approval}

the scientific ethical in the Department of biology - college of education for pure sciences recommended to allow Dr. Ali Al-Ali and his research team to use animal and human samples in them researches due to provide all laboratory requirements and training them to deal with samples using ethical methods required.

\section{RESULTS}

The treatment with calcitonin significantly decreased the rate of $\mathrm{Ca}+2$ in the blood of fish compared with the control group at a probability level $P \leq 0.05$ (Table 1, Figure 1-A).

Whereas, there were no significant differences in blood Ure and Crea rate between the fishes of the two groups although the rate of Ure in the blood of the treated fish was higher than that of the control group, but an increase was not significant (Table 1, Figure 1-B). The effect of CT on ALP enzyme was opposite to its effect on $\mathrm{Ca}+2$; there was a significant increase in ALP level in the blood of the treated fish at probability level $P \leq 0.05$ (Table 1, Figure 1-C).

As for the hormones Fsh and LH, the effect of CT was limited to LH without Fsh, where it was noted that there was a slight decrease in the rate of hormone Fsh in the serum of the treated group, as opposed to the hormone LH, which showed a significant increase at level of probability $P \leq 0.05$ in treated fish Serum compared with its level in control group (Table 1, Figure 1-D).

The histological study of the organs studied showed that CT did not show a clear effect on the liver tissue sections, the tissue sections in the treated fish group appeared to be intact (Figure 2-A, B). The histological examination revealed the effect of kidney tissue, the effect was concentrated in the renal tubules in particular, where necrosis was observed in the lining of the renal tubules (Figure 3-A, B, C), and alienation of the lining cells of tubules (Figure 3-C, D). In addition, there are masses of inanimate materials clumped into their cavities (Figure 3-C). 
The examination of the intestinal tissue sections revealed a hormone effect in the treated fish. A smooth swelling of smooth muscular cells was observed in outer layer of intestinal wall (Figure 4-A, B), with a pronounced thickening in its outer layer (Figure 4-B), and the intestinal epithelial lining was suffered of hyperplasia (Figure 4-C).

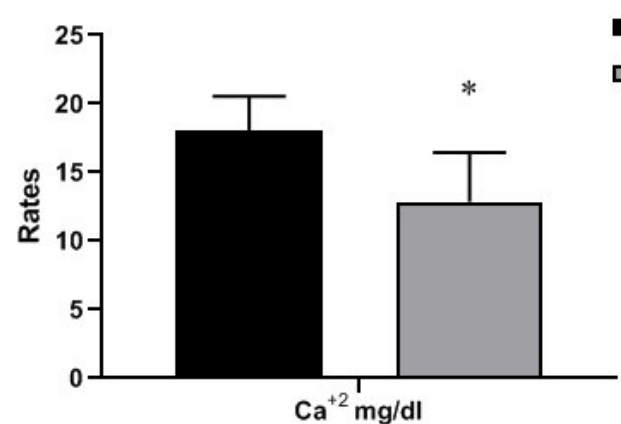

control

$\square$ treatment
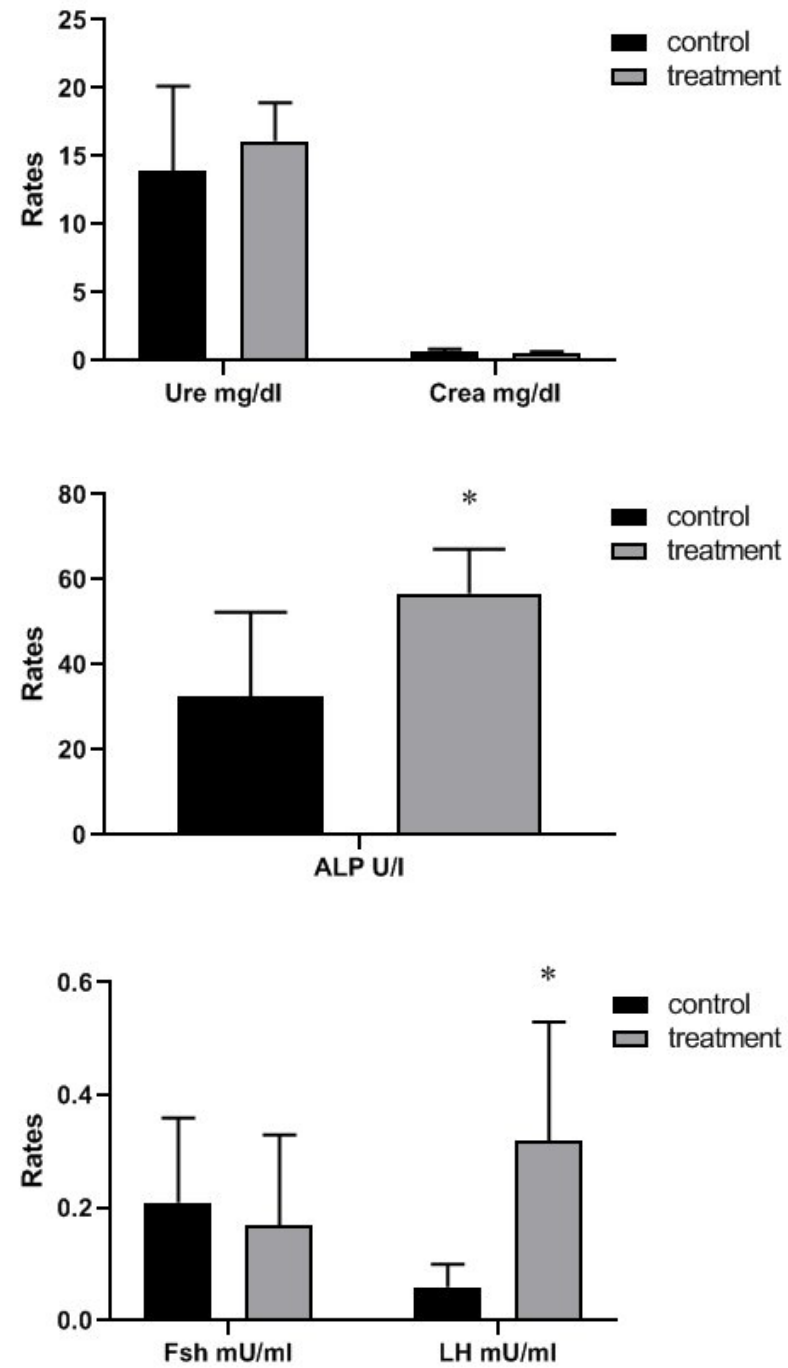

Fig. 1: Rates of biochemical parameters studied in serum for fish females for control and treatment groups: $\mathrm{Ca}+2$ (A), Ure and Crea (B), ALP (C), FSH and LH (D).

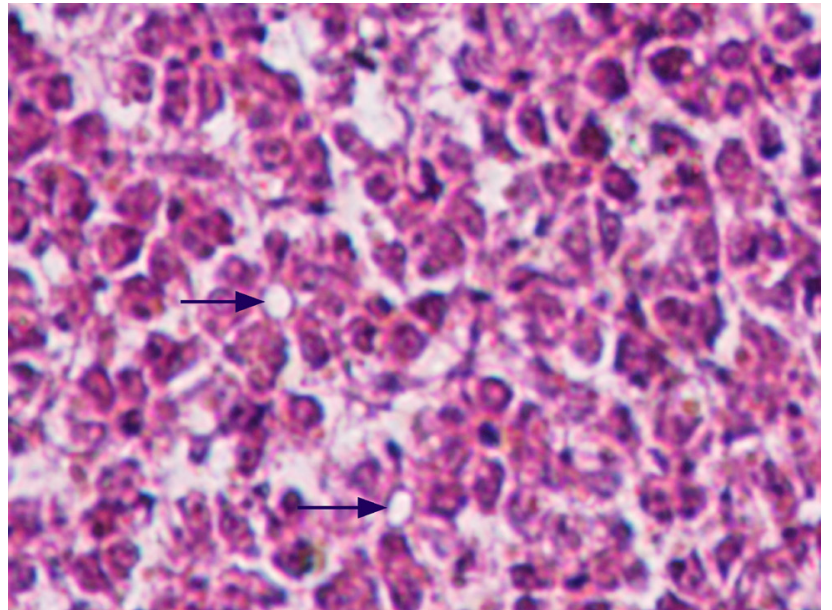

Fig. 2-A: A section of the liver after ten days of injection with physiological solution, showing hepatocytes that are organized into hollow tubes (arrows pointing to hepatic tubes). H\&E stain, 400X.

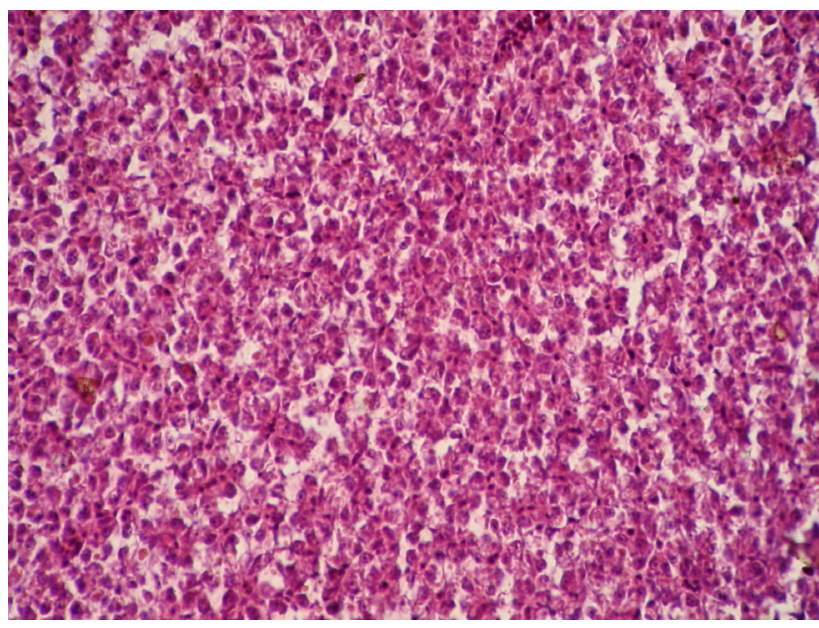

Fig. 2-B: A section of the liver Ten days after injection with CT, the tissue appears intact and no negative effects on liver cells. H\&E stain, 400X.

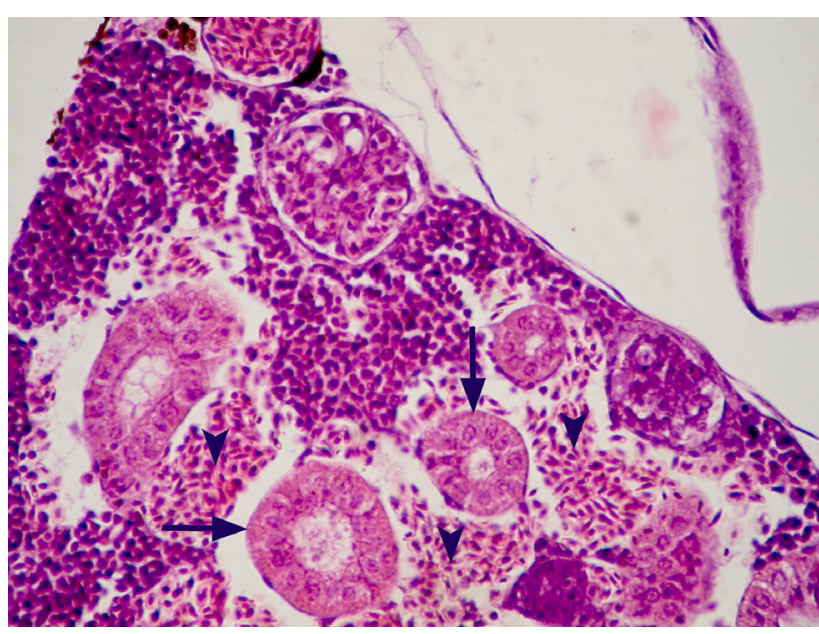

Fig. 3-A: A Section in kidney after ten days of injection with physiologica solution passes into the glomerulus, note the renal tubules (arrows) and hematopoietic tissue (arrowheads). H\&E tin stain, 400X. 


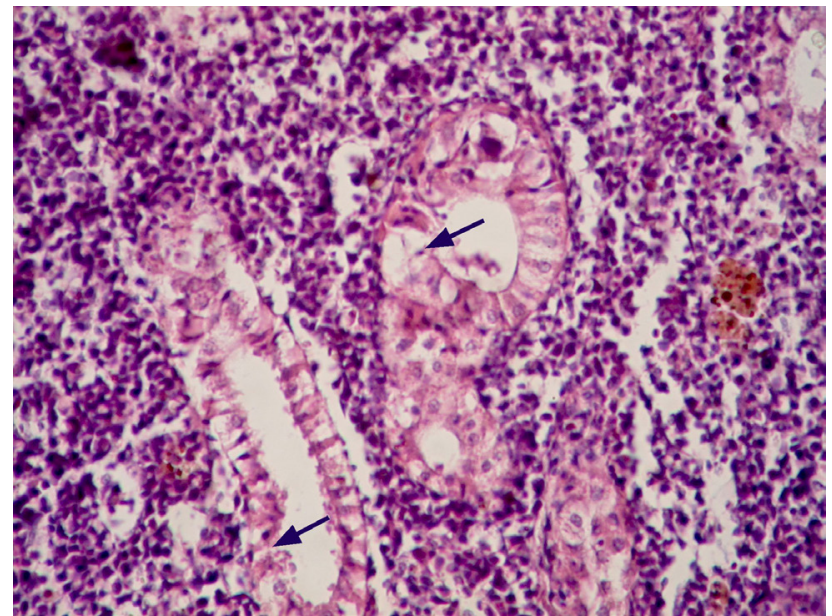

Fig. 3-B: A section in kidney of a sample ten days after CT injection, shows the necrosis of the renal tubule lining (arrows). H\&E stain, 400X.

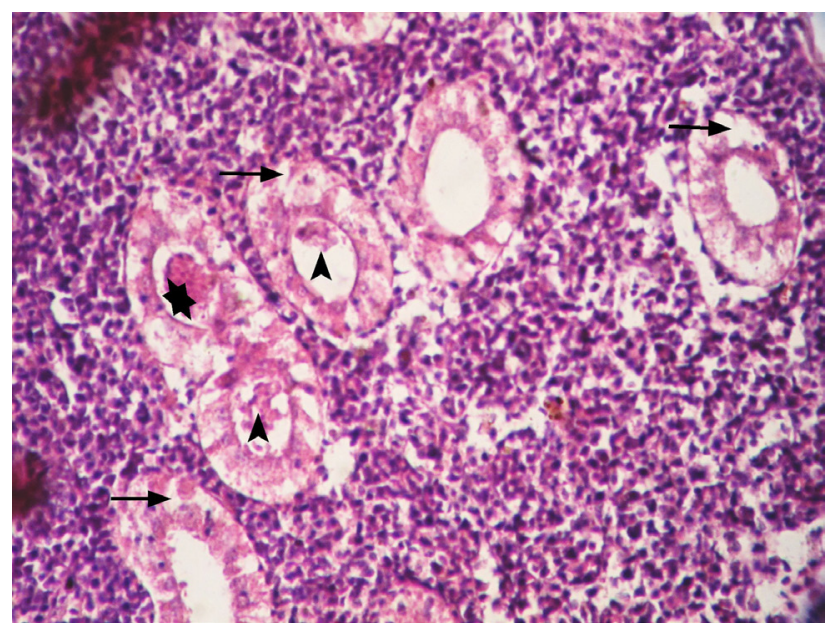

Fig. 3-C: A section in the kidney ten days after injection of CT, illustrates the necrosis of the lining of the renal tubules (arrows) and the alienation of their cells (arrowheads) and accumulation of non-living materials in their cavities (star). H\&E stain, 400X.

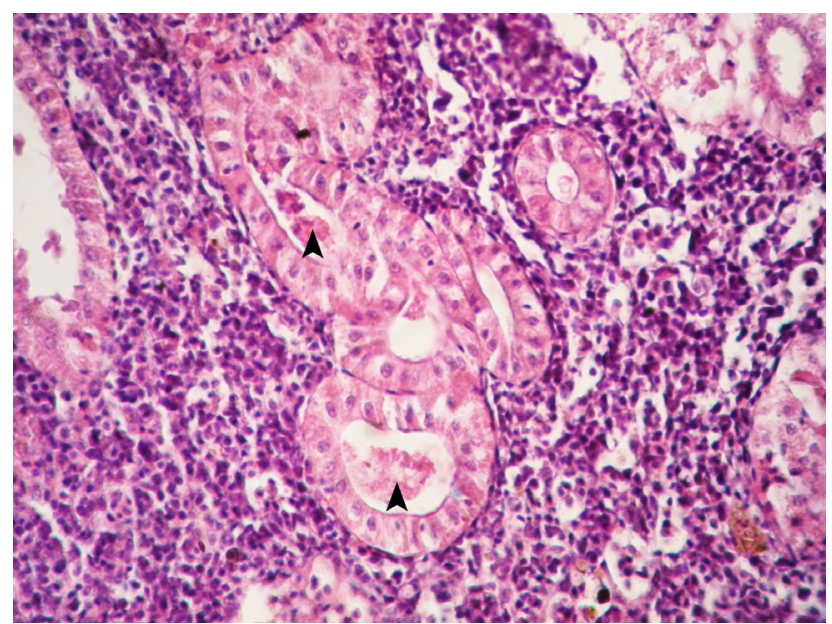

Fig. 3-D: A section in the kidney ten days after CT injection, shows alienation of some cells lining the cellular tubules (arrowheads). H\&E stain, 400X.

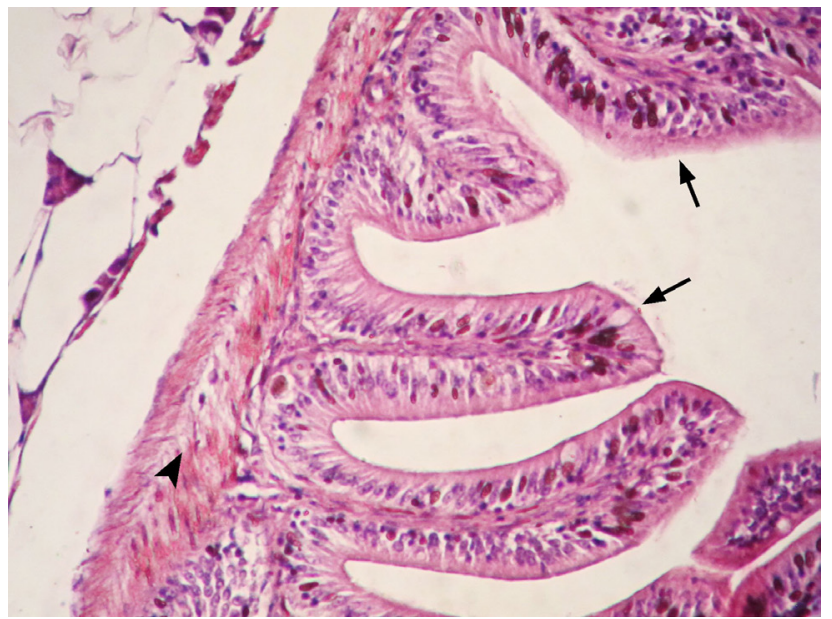

Fig. 4-A: A section in the small intestine ten days after injection with physiological solution, showing the presence of villi (arrows) on the inner wall of the intestine, note the smooth circular muscle layer (arrowhead). H\&E stain, 400X.

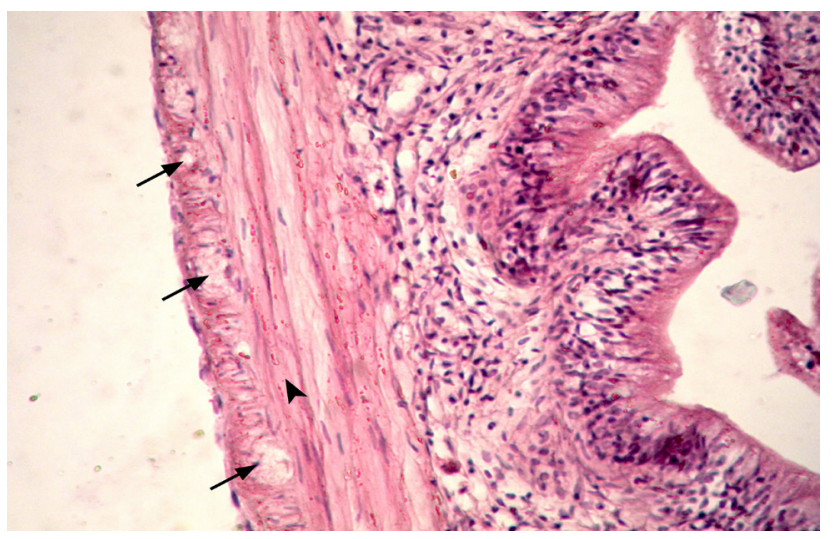

Fig. 4-B: A section in the small intestine of a sample Ten days after injection with CT, note the swelling of smooth muscular cells in outer muscular layer of intestinal wall (arrows) and the outer layer appears thickened (arrowhead). H\&E stain, 400X.

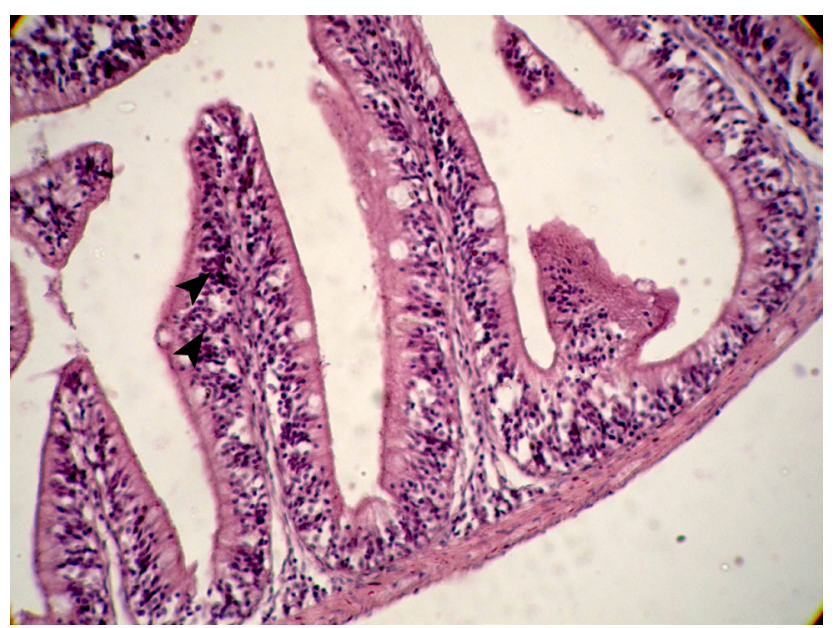

Fig. 4-C: A section into Intestinal of a sample after 10 days of treatment, illustrates hyperplasia (arrowheads) that occurs in the lining of intestinal epithelial tissue. H\&E stain, 400X. 
Table 1: Biochemical parameters rates in serum for fish females for control and treatment groups, and statistical differences between the two groups at probability level $P \leq 0.05$

\begin{tabular}{|c|c|c|c|c|c|c|c|c|}
\hline \multirow{2}{*}{ Parameter } & \multirow{2}{*}{ groups } & \multicolumn{5}{|c|}{ Duplicates } & \multirow{2}{*}{ mean \pm SD } & \multirow{2}{*}{$P$-value } \\
\hline & & 1 & 2 & 3 & 4 & 5 & & \\
\hline \multirow{2}{*}{$\mathrm{Ca}^{+2} \mathrm{mg} / \mathrm{dl}$} & Cont. & 21.6 & 18.35 & 17.35 & 14.55 & 18.2 & $18.01 \pm 2.52$ & \multirow{2}{*}{$0.03^{*}$} \\
\hline & Treat. & 17.9 & 9.2 & 11.3 & 15.2 & 10.65 & $12.85 \pm 3.59$ & \\
\hline \multirow{2}{*}{ Ure mg/dl } & Cont. & 19 & 17 & 18 & 11.5 & 4 & $13.9 \pm 6.24$ & \multirow{2}{*}{0.49} \\
\hline & Treat. & 14.5 & 14 & 15 & 16 & 21 & $16.1 \pm 2.83$ & \\
\hline \multirow{2}{*}{ Crea mg/dl } & Cont. & 0.65 & 0.91 & 0.4 & 0.5 & 0.76 & $0.64 \pm 0.20$ & \multirow{2}{*}{0.7} \\
\hline & Treat. & 0.63 & 0.56 & 0.7 & 0.55 & 0.6 & $0.60 \pm 0.06$ & \\
\hline \multirow{2}{*}{ ALP U/1 } & Cont. & 39.9 & 58 & 36.7 & 4.9 & 23 & $32.5 \pm 19.84$ & \multirow{2}{*}{$0.04^{*}$} \\
\hline & Treat. & 53 & 45 & 65 & 50.5 & 70 & $56.7 \pm 10.42$ & \\
\hline \multirow{2}{*}{ Fsh $\mathrm{mU} / \mathrm{ml}$} & Cont. & 0.22 & 0.07 & 0.36 & 0.37 & 0.03 & $0.21 \pm 0.15$ & \multirow{2}{*}{0.74} \\
\hline & Treat. & 0.08 & 0.05 & 0.43 & 0.07 & 0.25 & $0.17 \pm 0.16$ & \\
\hline \multirow{2}{*}{$\mathrm{LH} \mathrm{mU} / \mathrm{ml}$} & Cont. & 0.11 & 0.02 & 0.065 & 0.01 & 0.1 & $0.06 \pm 0.04$ & \multirow{2}{*}{$0.02^{*}$} \\
\hline & Treat. & 0.32 & 0.19 & 0.1 & 0.66 & 0.35 & $0.32 \pm 0.21$ & \\
\hline
\end{tabular}

\section{DISCUSSION}

Calcitonin is involved in the regulation of blood calcium in most animal classes ${ }^{[1]}$. Although some studies have failed to demonstrate clearly its role in the regulation of $\mathrm{Ca}^{+2}$ in fish blood[4,10,11]. However, several studies have shown that it causes Hypocalcemia in the blood of some species $^{[5,7,31,32]}$. The results of the current study support these studies in that calcitonin has a role in regulating the level of calcium in fish blood.

The mechanism of calcitonin regulation of $\mathrm{Ca}^{+2}$ in fish blood varies, with some seeing it inhibiting the activity of Osteoclasts cells ${ }^{[5,19]}$, or inhibition of Osteoclasts cells and enhance the activity of Osteoblasts cells at the same time $^{[1,33]}$. However, the histological study and examination of the concentrations of the mineral elements of the teeth and their bony bases for P. latipinna showed no clear effect on the hormone ${ }^{[7]}$. Alsaray ${ }^{[7]}$ explained CT role in regulating $\mathrm{Ca}^{+2}$ away from metallic tissues, and this interpretation is acceptable based on some studies. Okuda et al. ${ }^{[18]}$ found at that the hormone is produced topically in the intestinal lining of Goldfish and inhibits calcium absorption during feeding. CT hormone may have influenced the osmotic regulation of the epithelial lining of the gills as one of the main tissues targeted for this hormone in fish and inhibited the calcium transport through the gills ${ }^{[6,34,35]}$. Or the effect may be due to the synergy of its role in the intestines and gills away from calcified tissues, a possibility embraced by Alsaray ${ }^{[7]}$ on P. latipinna. The present study partly agrees with this possibility, as the expression for CGRPR gene; one the hormone receptor, is found in both intestines and gills in fish Paralichthys olivaceus ${ }^{[20]}$. This indicates into the actual role of the hormone in those organs, but the role of the hormone can not be excluded from calcified tissue in fish. This is not consistent with the Alsaray study ${ }^{[7]}$, because it examined the effect of CT on bone in a specific area, it is not necessary for all bones to have CT hormone receptors. The absence of the gene expression of the hormone receptor CGRPR in the spine bones of the flounder was observed ${ }^{[20]}$. Perhaps, the nature of the fish bone makes it difficult to observe changes in bone at the histological level, and the exposure duration or dose level may not cause the histological changes.

The results show that calcitonin has not shown a clear effect on both Ure and Crea, which are usually tested in the blood as an indicator of animal health, including fish. Increased or decreased levels of secretion is usually caused by impaired kidney and liver function. Results analysis shows no significant differences between the control and treatment groups; therefore, CT probably did not affect the function of these organs - kidney and liver - and each organ functioned normally in the production and secretion of Ure and Crea. the stability of Ure within normal limits means that the rate of metabolism of proteins and therefore general metabolism was constant unaffected. Furthermore, the normal limits of Crea an indicator of the safety of Creatine metabolism, therefore an indication of the stability of the muscular activity of fish ${ }^{[1]}$, especially since it was not observed no lethargy or increased activity on fish movement during the experiment period. This possibility is supported by the results of liver tissue sections, which did not show a clear effect with CT. However, the results of the tissue sections of kidney showed a clear effect with $\mathrm{CT}$, which means that the effect has reached the kidney; but not extent that affects its function, for reasons that may be related with the amount of dose or the period of injection in which the fish were treated. It is noteworthy that no previous study dealt with the effect of this hormone on the Ure and Crea levels in the blood to our knowledge.

ALP is produced by several organs in the body, and its elevation or decrease in serum above normal is a criterion for damage to those organs alone or in combination ${ }^{[27]}$. Numerous studies have indicated a correlation between 
CT and this enzyme, accordingly a correlation with tissue producing it, regardless of the type of relationship, whether negative or positive. As it Miyamoto et al..$^{[36,37]}$ observed that CT works to regulate and increase ALP activity in cells line LLC-PK1 derived from kidney of pig. The hormone altered enzyme levels in patients with Paget's disease of bone $^{[38]}$. An increase in ALP enzyme was observed in rats when it administered CT subcutaneously ${ }^{[39]}$. While CT was negatively associated with ALP in cats infected with chronic kidney disease ${ }^{[40]}$.

The results of the high level of ALP in blood clearly indicate to effect of CT in tissue produced for this enzyme, but the current study excludes the role of liver cells in the rise of ALP, because the levels of Ure and Crea in blood not affected, which means function safety. On the other hand, not affected liver cells during injection period, this is appearing in histological sections. But this study assumes that kidney cells are involved in its secretion; based on studies showing that $\mathrm{CT}$ has the ability to excite kidney cells to secrete this enzyme ${ }^{[36,37]}$. In particularly, the results of the tissue sections have shown that the hormone effect has reached kidney cells. The intestines are as one of the secreting organs of the enzyme ALP ${ }^{[27]}$, they contain CT receptors ${ }^{[20]}$. Its tissue sections have shown a clear influence with it, and they may have been involved in secreting this enzyme.

The high level of ALP may be attributed to bone tissue, which is the most likely. Because $\mathrm{Ca}^{+2}$ decreases in blood by $\mathrm{CT}$ which an means increase activity of Osteoblasts cells more than Osteoclasts cells ${ }^{[1,33]}$. References suggest that increased activity of Osteoblasts cells increases their release of ALP ${ }^{[1,41]}$. Studies have shown that CT at certain concentrations increases ALP activity and level through its activity on osteoblasts cells ${ }^{[42,43]}$. One study reported that calcitonin increased the level of this enzyme in cartilage cell culture of the rabbit ${ }^{[44]}$. This also adds the possibility that the cartilage cells in the fish have been involved in increasing the level of ALP due to hormone. Al-Ali ${ }^{[45]}$ has shown that the skeleton of molly fish contains large amounts of cartilage tissue forms pulp for bone. The present study assumes that Osteoblasts cells had the greatest role in increasing the secretion of ALP, because of low $\mathrm{Ca}^{+2}$ in serum due to CT. In addition to kidney cells and intestines that showed a clear impact on the sections of the tissue, and do not rule out the cartilage tissue for lack of examination.

Sex hormones FSH and LH are extremely important, so any rise or decrease in their level in blood will cause many problems. The results showed that FSH was not shown to be affected by CT, but that LH has increased with significant differences. But there have been studies on the effect of CT on other sex hormones, particularly on fish. After high plasma CT levels were observed during the peak breeding season in different species ${ }^{[12-14]}$. It was found that CT hormone increases the level of hormone $17 \beta$-estradiol in plasma ${ }^{[13-15,17]}$. It was also found that the hormone has a role in steroids production and oocyte maturation in ovarian follicles ${ }^{[5,14]}$. All these are indications that calcitonin is related to the reproduction process in fish. and this is supported by the present study based on the results of the rise of LH in serum affected by $\mathrm{CT}$.

\section{ACKNOWLEDGMENTS}

We would like to express our gratitude to (Laboratories of Biology Department/college of Education for Pure Science/Basrah University, Iraq).

\section{CONFLICTS OF INTEREST}

There are no conflicts of interest.

\section{REFERENCES}

1. Hall JE: Guyton and Hall Textbook of Medical Physiology. 13th. ed., Elsevier Health Sciences. (2016) P: 1264.

2. Felsenfeld AJ and Levine BS: Calcitonin, the forgotten hormone: does it deserve to be forgotten? Clinical kidney. (2015) 8(2): 180-187.

3. Chan DKO, Jones IC, and Smith RN: The effect of mammalian calcitonin on the plasma levels of calcium and inorganic phosphate in the European eel (Anguilla anguilla L.). General and Comparative Endocrinology. (1968) 11(1): 243-245.

4. Bonga SW and Pang PKT: Control of calcium regulating hormones in the vertebrates: parathyroid hormone, calcitonin, prolactin, and stanniocalcin. International Review of Cytology. (1991) 128: $139-213$.

5. Mukherjee D, Kundu S, Pramanick K, Paul $\mathrm{S}$ and Mallick B: Calcitonin Functions Both as a Hypocalcemic Hormone and Stimulator of Steroid Production and Oocyte Maturation in Ovarian Follicles of Common Carp, Cyprinus carpio. InTech. (2011) (65): 279-312.

6. Lafont AG, Wang YF, Chen GD, Liao BK, Tseng YC, Huang CJ and Hwang PP: Involvement of calcitonin and its receptor in the control of calcium-regulating genes and calcium homeostasis in zebrafish (Danio rerio). Bone and Mineral Research. (2011) 26(5): 1072-1083.

7. Alsaray ST: Study of Morphometry and Development of Teeth of Sailfin Black Molly Fish Poecilia latipinna Under the Influence of Calcitonin Hormone. Master Thesis. Basra University. (2017) (In Arabic).

8. Dacke CG: Calcium regulation in sub-mammalian vertebrates. Academic Press. New York and London. (1979).

9. Copp DH and Kline L: In "Vertebrate Endocrinology: Fundamentals and Biomedical Implications" (P. K. T. Pang and M. P. Schreibman, eds.). Academic Press, San Diego, California. (1989) (3): 79. 
10. Singh $\mathrm{S}$ and Srivastav AK: Effects of calcitonin administration on serum calcium and inorganic phosphate levels of the fish, Heteropneustes fossilis, maintained either in artificial freshwater, calcium-rich freshwater, or calcium-deficient freshwater. (1993).

11. Srivastava AK, Singh S, Mishra D and Srivastava SK: Ultimobranchial gland of freshwater catfish, Heteropneustes fossilis, in response to calcitonin administration. Pesquisa Veterinária Brasileira. (2009) 29(12): 963-968.

12. Yamauchi H, Orimo H, Yamauchi K, Takano K and Takahashi H: Increased calcitonin levels during ovarian development in the eel, Anguilla japonica. General and Comparative Endocrinology. (1978) 36(4): 526-529.

13. Björnsson, B. T.; Haux, C.; Förlin, L. and Deftos, L. J. (1986). The involvement of calcitonin in the reproductive physiology of the rainbow trout. Journal of Endocrinology, 108(1): 17-23.

14. Suzuki N, Yamamoto K, Sasayama Y, Suzuki T, Kurokawa T, Kambegawa A, ... and Kikuyama S: Possible direct induction by estrogen of calcitonin secretion from ultimobranchial cells in the goldfish. General and Comparative Endocrinology. (2004) 138(2): 121-127.

15. Verma SK and Alim A: Ultimobranchial gland respond in a different way in male and female fresh water teleost Mastacembelus armatus (Lacepede) during reproductive cycle. Animal reproduction science. (2015) 156: 111-117.

16. Björnsson BT, Haux C, Bern HA and Deftos LJ: 17ß-estradiol increases plasma calcitonin levels in salmonid fish. Endocrinology. (1989) 125(4): 1754-1759.

17. Paul S, Mukherjee D, Pramanick K, Kundu S, Bhattacharyya SP, De P and Mukherjee $D$ : Stimulation of salmon calcitonin on secretion of $17 \beta$-estradiol by the ovarian follicles of common carp, Cyprinus carpio. Endocrinology. (2008) 196(2): 413-424.

18. Okuda R, Sasayama Y, Suzuki N, Kambegawa A and Srivastav A K: Calcitonin cells in the intestine of goldfish and a comparison of the number of cells among saline-fed, soup-fed, or high Ca soup-fed fishes. General and Comparative Endocrinology. (1999) 113(2): 267-273.

19. Suzuki N, Suzuki T and Kurokawa T: Suppression of osteoclastic activities by calcitonin in the scales of goldfish (freshwater teleost) and nibbler fish (seawater teleost). Peptides. (2000a) 21(1): 115-124.
20. Suzuki N, Suzuki T and Kurokawa T: Cloning of a calcitonin gene-related peptide receptor and a novel calcitonin receptor-like receptor from the gill of flounder, Paralichthys olivaceus. Gene. (2000b) 244(1): 81-88.

21. Hidaka Y, Tanaka S and Suzuki M: Analysis of salmon calcitonin I in the ultimobranchial gland and gill filaments during development of rainbow trout, Oncorhynchus mykiss, by in situ hybridization and immunohistochemical staining. Zoological Science. (2004) 21(6): 629-637.

22. Clark MS, Bendell L, Power DM, Warner S, Elgar $\mathrm{G}$ and Ingleton PM: Calcitonin: characterisation and expression in a teleost fish, Fugu rubripes. Molecular Endocrinology. (2002) 28(2): 111-123.

23. Veldman $\mathrm{MB}$ and Lin $\mathrm{S}$ : Zebrafish as a developmental model organism for pediatric research. Pediatric Research. (2008) 64(5): 470-476.

24. Ribas L and Piferrer F: The zebrafish (Danio rerio) as a model organism, with emphasis on applications for finfish aquaculture research. Reviews in Aquaculture. (2014) 6(4): 209-240.

25. Schartl M: Beyond the zebrafish: diverse fish species for modeling human disease. Disease models \& Mechanisms (2014) 7(2): 181-192.

26. Bootorabi F, Manouchehri H, Changizi R, BarkerH, Palazzo E, Saltari A, ... and Aspatwar A: Zebrafish as a Model Organism for the Development of Drugs for Skin Cancer. International Journal of Molecular Sciences. (2017) 18(7): 1550.

27. Fishman WH: Perspectives on alkaline phosphatase isoenzymes. The American journal of medicine. (1974) 56 (5): 617-650.

28. Yu WH, Kimura M, Walczewska A, Karanth S and McCann SM: Role of leptin in hypothalamicpituitary function. Proceedings of the National Academy of Sciences. (1997) 94(3): 1023-1028.

29. Dalkin AC, Haisenleder DJ, Gilrain JT, Aylor $\mathrm{K}$, Yasin $\mathrm{M}$ and Marshall JC: Gonadotropinreleasing hormone regulation of gonadotropin subunit gene expression in female rats: actions on follicle-stimulating hormone $\beta$ messenger ribonucleic acid (mRNA) involve differential expression of pituitary activin $(\beta-B)$ and follistatin mRNAs. Endocrinology. (1999) 140(2): 903-908.

30. Humason GL: Animal tissue techniques. $3^{\text {rd }}$. ed., W.H. Freeman and Company, San Francisco. (1972) P: 614.

31. Chakrabarti P and Mukherjee D: Studies on the hypocalcemic actions of salmon calcitonin and ultimobranchial gland extracts in the freshwater teleost Cyprinus carpio. General and Comparative Endocrinology. (1993) 90(3): 267-273. 
32. Suzuki N, Suzuki D, Sasayama Y, Srivastav AK, Kambegawa A and Asahina K: Plasma calcium and calcitonin levels in eels fed a high calcium solution or transferred to seawater. General and Comparative Endocrinology. (1999) 114(3): 324-329.

33. Shinozaki F and Mugiya Y: Histomorphometric effects of calcitonin on pharyngeal bone in fed and starved goldfish Carassius auratus. Fisheries science. (2002) 68(2): 269-276.

34. Milhaud G, Rankin JC, Bolis L and Benson AA: Calcitonin: its hormonal action on the gill. Proceedings of the National Academy of Sciences. (1977) 74(10): 4693-4696.

35. Mukherjee D, Sen U, Bhattacharyya SP and Mukherjee D: Inhibition of whole body $\mathrm{Ca} 2+$ uptake in fresh water teleosts, Channa punctatus and Cyprinus carpio in response to salmon calcitonin. Experimental Zoology Part A: Ecological Genetics and Physiology. (2004) 301(11): 882-890.

36. Miyamoto KI, Horita T, Waki Y, Suzuki R, Yamamoto $\mathrm{S}$ and Moritani $\mathrm{S}$ : Dual regulation of alkaline phosphatase activity by calcitonin in porcine kidney cells. Biological and Pharmaceutical Bulletin. (1997) 20(12): 1300-1302.

37. Miyamoto KI, Suzuki R, Horita T, Yamamoto S, Waki Y and Takagi K: Role of phosphodiesterase 4 isoenzyme in alkaline phosphatase activation by calcitonin in porcine kidney LLC-PK1 cells. The Japanese Journal of Pharmacology. (1998) 76(2): 193-198.

38. Elshafie O, Alsaffi N, Hussain S and Woodhouse $\mathrm{N}$ : Paget's disease in an Omani: long-term improvement following a single injection of zoledronic acid. Oman medical journal. (2016) 31(2): 146

39. Ersozlu S, Sarisozen B, Ozer O, Adim SB and Sahin O: The biochemical and histological analysis of subcutaneous calcitonin and intramedullary methylprednisolone on bone repair after bone marrow ablation: an experimental comparative study in rats. Journal of experimental orthopaedics. (2017) 4(1): 25.

40. Geddes RF, Williams TL, Chang YM, Elliott J and Jepson RE: Calcitonin Response to Naturally Occurring Ionized Hypercalcemia in Cats with Chronic Kidney Disease. Journal of veterinary internal medicine. (2018) 32(2): 727-735.

41. Zancanela DC, Sper Simão AM, Matsubara EY, Rosolen JM and Ciancaglini P: Defective multilayer carbon nanotubes increase alkaline phosphatase activity and bone-like nodules in osteoblast cultures. Journal of nanoscience and nanotechnology. (2016) 16(2): 1437-1444.

42. Farley JR, Wergedal JE, Hall SL, Herring S and Tarbaux NM: Calcitonin has direct effects on 3(H)-thymidine incorporation and alkaline phosphatase activity in human osteoblast-line cells. Calcified tissue international. (1991) 48(5): 297-301.

43. Farley JR, Hall SL and Herring S: Calcitonin acutely increases net $45 \mathrm{Ca}$ uptake and alters alkaline phosphatase specific activity in human osteosarcoma cells. Metabolism. (1993) 42(1): 97-104.

44. Kato Y, Shimazu A, Nakashima K, Suzuki F, Jikko A and Iwamoto M: Effects of parathyroid hormone and calcitonin on alkaline phosphatase activity and matrix calcification in rabbit growth-plate chondrocyte cultures. Endocrinology. (1990) 127(1): 114-118

45. Al-Ali AA: Differentiation in some types of connective tissue in black molley Poeceilia sphenops. PHD. Thesis. Basra University. (2008) (In Arabic). 